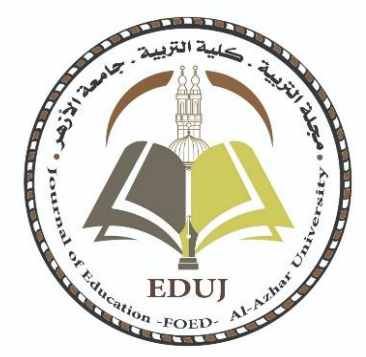

\title{
The Effectiveness of a Computerized Simulation-Based Educational Program in Developing Reading and speaking skills for the 3rd Grade
}

\author{
Ala'a Yahya Al-Fogara \\ Master in Curricula and methods of teaching English, The \\ Ministry of Education, Jordan - Al-Karak \\ Prof. Khalaf Al-Sagrat \\ Professor of Curriculum and Instruction, Department Of \\ Curriculum And Teaching, Faculty of educational sciences, \\ Mutah University- Jordan
}




\section{فاعلية برنامج تعليمي محوسب قائم على المحاكاة في تنمية

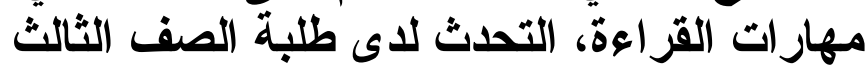

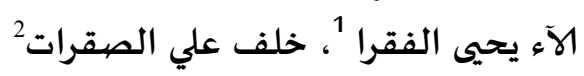

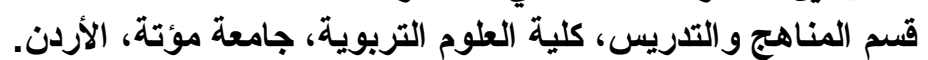
1البريد الاكتروني للباحث الرئيس: alaa_fagara@yahoo.com

تهدف الدراسة الحالية إلى استقصاء فعالية برنامج تعليمي محوسب قائم على المحاكاة في تنمية مهارات القراءة والمحادثة لدى طلاب الصف الثالث في اللغـة الإنجليزية. حاولت الدراسـة الإجابة عن الأسئلة الآتية : ما فاعلية البرنامج التعليمي المحوسب القائم على المحاكاة في تنمية مهارات القـراءة والمحادثة لـدى طلبـة الصف الثالث بين المجموعـة التجريبيـة (والتي درست بإسـتخدام البرنـامج التعليمي المحوسب القائم على المحاكاة) والمجموعـة الضـابطة (والتي درسـت بالطريقة الاعتياديـة)؟ وهل هنـاك فروق ذات دلالـة احصيائية عند مستوى الدلالـةa التحـصيل بـين أداء الطلبـة في المجموعـة التجريبيـة التي درسـت بإسـتخدام البرنـامج التعليهي المحوسب القائم على المحاكاة على مهارتي القراءة والتحسدث ؟ وتكون مجتمع الدراسـة من 365 طالبـاً يدرسـون في المـارس الخاصـة في تربيـة قصبـة الكرك و تكونـت عينـة الدراســة مـن (30)

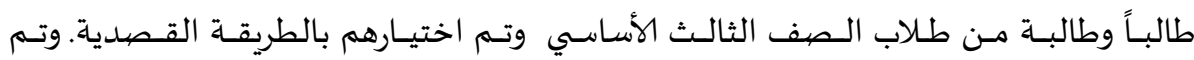

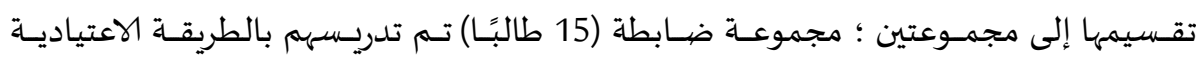

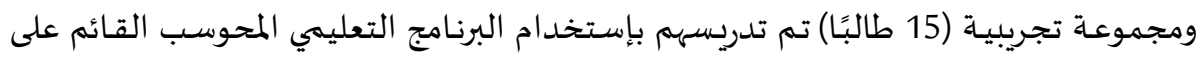

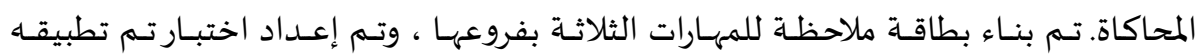
بـصورة قبليـة وبعديـة ، وبرنـامج تعليمي محوسـب قـائم على المحاكاة ، وتـم إجـراء معـاملات

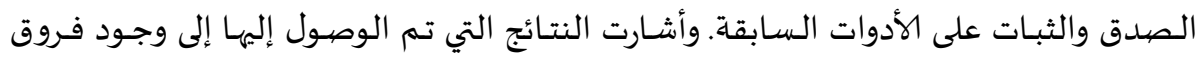

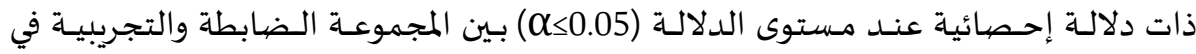
تنميـة مهارات (الاستماع ، والقـراءة ، والمحادثـة) لـدى الطلاب ولـصالح المجمموعـة التجريبيـة. في ضـوء نتـائج هـذه الدراسـة توصي الباحثـة بمـا يلي: على وزارة التربيـة والتعليم في الأردن ضـرورة زيـادة الاهتمـام والتركيز على توظيـف التكنولوجيـا والبيرامج التعليميـة المحوسـبـة القائمـة على المحاكاة في تـدريس المهـارات المختلفـة. واسـتخدام هـذه التقنيـة في قاعـات الدراسـة بالمـدارس وإجراء المزيد من الدراسات حول عينات أخرى ومواد دراسية أخرى. الكلمات المفتاحية: برنامج تعليمي محوسب قائم على المحاكاة، مهارة القراءة ، مهارة المحادثة. 


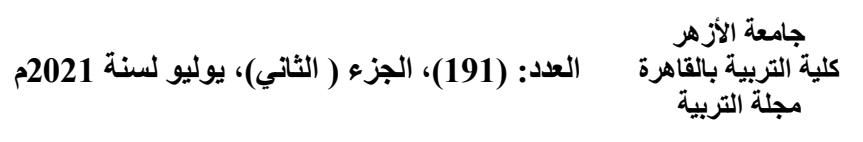

The Effectiveness of a Computerized Simulation-Based Educational Program in Developing Reading and speaking skills for the 3rd Grade

Ala'a Yahya Al-Fogara ${ }^{1}$, Khalaf Al-Sagrat ${ }^{2}$.

Department Of Curriculum And Teaching, Faculty of educational sciences, Mutah University- Jordan.

${ }^{1}$ Corresponding author E-mail alaa_fagara@yahoo.com

\begin{abstract}
This current study aims to investigate the effectiveness of a Computerized Simulation-Based Educational Program In Developing Reading and Speaking skills for the 3rd Grade Students in The English Language. This study attempted to answer the following questions: What is the effectiveness of a Computerized SimulationBased Educational program on developing student's reading and speaking skills between the experimental group (which was studied using the computerized simulation-based educational program) and the control group (which was studied in the usual way)? Are there any statistical significant differences at $(a<0.05)$ in the achievement between the students' performance in the two skills due to the Computerized Simulation-Based Educational program? The population of the study consisted of 365 students who are studying at the private schools in Al-Karak directorate and sample of the study consisted of (30) male and female of the third grade students and they were selected by the Intentional method. And it was divided into two groups; control group (15 students ) were taught in the usual way and experimental group (15 students) were taught with a Computerized Simulation-Based Educational program . The observation cards were constructed with the sub-skills of the three skills, pre/post tests were constructed and applied and a Computerized Simulation-Based Educational program where validity and reliability were ensured for the previous tools. The results of the study indicated that there were significant statistical differences at $(\alpha \leq 0.05)$ between the control and the experimental group in developing student's Reading, and Speaking skills in favor of the experimental group. In the light of the findings of this study, the researcher recommends the following : The Ministry of Education in Jordan should increase attention and focus on employing technology and computerized educational programs based on simulations in teaching different skills And the use of this technology in the classroom of schools and conducting more studies on other samples and other subjects.
\end{abstract}

Keywords: a Computerized Simulation-Based Educational Program, Reading skill, speaking skill. 


\section{Introduction} technology.

We are living in the $21^{\text {st }}$ Century which is regarded as an era of

Technology, today, plays very important role in our life. This is because technology makes our work much easier and less time consuming.

According to (Wallace 1992, as cited in AlNatour \& Hijazi (2018) English Language plays a crucial role these days. It is one of the main elements in any educational system.

As a result, English Language is taught at schools and universities in all over the world. In some countries it is taught as a second language or a foreign language .

English Language considered as one of the basic international language in the world. It can be in science, technology and economic.

Ismaiel (2017) said that the most important and vital way in processing information is Reading.

Reading is a vital skill for everyone and it is a lifelong skill to be used in everywhere such as schools, universities and hospitals.

Miculecky \& Jeffries (2004) declared that reading skill is very important since it can enhance students' general language skill in English. Also, it is helping students to think in English and increasing students' English vocabulary and improving their writing skill. Reading skill occupies a substantial place in enrichmenting students' vocabulary.

Learning English is often related to how to speak language. No doubt that speaking skill is a primacy for many EFL learners and teachers.

UR(1996) declares that speaking skill seems intuitively the most important skill of the four skills which are reading, listening and writing, because people who know a language are referred to as a speaker of the language, as if speaking included all other kinds of knowing and many if not most foreign language learners are primarily interested in learning to speak.

Also, Speaking skill is a very important skill to acquire a foreign language, because when you read words, written ideas and thoughts heard, all what you need is to express your speaking skill.

According to Srinivas Rao (2019), Speaking skill is the most important skill in learning a foreign or a second language. Speaking seems to be difficult because the speaker have to produce sentences without learning grammatical structures and having proper knowledge to adequate vocabulary. Speaking skills are the most main skills for all the learners who wish and try to learn English to promote their career and self-confidence, get better job opportunities and participate in debates and group discussions. 
We live in a world in which a change is a norm and students need to learn English in an appropriate way to cope with the world of technology. As a result, teachers need to use modern strategies to enhance students' skills learning such as, CALL (Computer Assisted Language Learning), drama, Simulation and role-play .(Rohani \& Pourgharib 2013)

Harmer (2003) asserted that reading skill is one of the receptive skills of English language. And according to Kucuoglu (2013) the main purpose of reading is to make the underlying meaning visible and clear, and the goal of the readers is to understand the text they read.

Simulation is a technique for learning that can be applied in many different disciplines and types of learners.

As Cambridge Business English Dictionary (2011) Simulation is the use of situation or events that seem real but are not real, especially in order to help people to deal with such situations or events.

Simulation has been proposed as a technique to close the gap between the classroom and the real environment. Simulation has been intertwined with the language techniques in the university classrooms for decades. This technique was integrated in the classroom in the late 1950 's and early 1960's, and after this decade, simulation has increasingly been used as a teaching technique (Shaw, 2010).

The main key of feature of simulation is that it creases real-life like environment. (Turan, 2015)

Simulation is usually preferred when the real events are dangerous, expensive and harmful or not safe. Simulation provides the students with safe opportunities to practice and develop their skills. (De Jong \& Lane \& Sharp, 2012)

Simulation based learning could be a strategy that will assist teachers to reach and teach vocabulary to their students, giving their students a greater access to their learning and academic success.

Simulation can provide safe opportunities for the beginners to practice and improve their skills, because simulation is preferred when the real life is dangerous, expensive and harmful.(De Gong, Lane and sharp, 2012)

\section{Statement of the problem}

The problem of the study stems from the researcher's survey of the evidence indicating the low level of students' reading and speaking skills in the English language, such as the statement of the Director of Examinations at the Ministry of Education; Ajarmeh (2018), which indicated that reading and speaking skills were evaluated by the ETS Foundation in cooperation with British Council for the sixth and seventh grades in the three regions of the Kingdom, and the results were sub-standard. 
Also, by informing the researcher on the previous studies in the field of developing reading and speaking skills, the researcher found some studies such as

By looking at the statements above and the researcher observation, the researcher found some problems at the third grade students in the English language class. They took much time in reading the sentences. Reading skill, they do not use attractive ways to ensure interaction between students. Therefore, teachers of English as a Foreign Language (EFL) would do well to develop learners' reading skill and equip them with the strategies for effective reading .

The teaching and learning process in the primary stage especially in English Language needs a special technique in order to gain the necessary skills for the students.

According to the researcher observation, the English subject in the third grade is still undesirable, traditional and conventional. Also, The researcher noticed that some Jordanian teachers still using traditional ways in teaching reading and speaking skills neglecting using modern methodologies, such as simulation since we are living in the age of technology, and it is important that we incorporate technology in all fields of our life including education.

Simulation comes to remedy this dilemma as it models real-life situations where reading is interactively used and activates effective communication as a need to achieve different functional purposes and not as a goal (Sharifi \& Ghanizadeh \& Jahedizadeh, 2017)

And simulation helns in increasing the students level of confidence bv providing them classroom activities similar to the realitv. although some researchers contend that learning in a simulated setting gives learners a safe and supportive environment.

\section{Significance of the study}

It is hoped that, this study may give insight to educators in the Ministry of Education and teachers of English as a Foreign Language (EFL) where they may improve and fit a simulation into developing reading and speaking skills.

There are few studies that deal with this topic specially at the primary stage, so this study may motivate other researchers to investigate the same field with different variables to unravel some obstacles which hinder learning the English Language.

\section{The Purpose of the Study}

The purpose of this study is to investigate The Effectiveness of a Computerized Simulation-Based Educational Program In Developing, Reading and speaking skills for the 3rd Grade Students. 


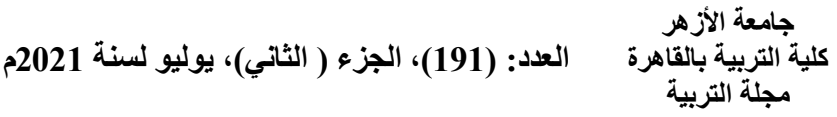

\section{Questions of the Study}

The purpose of the study will be achieved through answering the following questions :

1) What is the effectiveness of a Computerized Simulation-Based Educational program on developing students' reading and speaking skills between the experimental group (which was taught using the computerized simulation-based educational program) and the control group (which was taught by the usual way)?

2) Are there any statistical significant differences at $(a<0.05)$ between the students' performance in the two skills due to the Computerized Simulation-Based Educational program?

\section{Operational Definitions of terms}

1. the Computerized simulation-based Educational program: It is a computerized educational program designed and developed by a team of professionals, which aims to develop reading and speaking skills for the third grade students, and it contains of two educational units and included with pictures, audios, videos and colors that simulates the reality in a safe environment, in order to attract the students' attention and encourage them to practice reading and speaking skill freely without a high cost or dangerous.

2. Reading skill : It is the ability to read and pronounce the words which appear in the Computerized simulation-based Educational program speedily and correctly with a high self-confidence.

3. speaking skill : It is an interactive process, where the students try to speak and answer the comprehension questions in the educational program according to some criteria like Fluency and accuracy grammatical with a high self-confidence. Also, it is the ability to describe the pictures with a correct grammatical sentences.

4. Third grade students : They are the students who are studying English Language in the primary stage in Jordan. They are usually between 8-9 years old.

\section{Limitation of the study}

This study is limited to the third grade students at all private schools in AlKarak, Jordan, And Their English students' book.

Also, it is limited to simulation in teaching. And it is limited to develop reading and speaking skills which it is essential element to practice English Language fluently.

\section{Literature Review:}

Angelini (2019). conducted a study on developing English speaking skills through simulation-based-instruction. In this study a group of university engineering students were taught with simulation 
to aid their learning of English as a foreign language. These engineering students were taught English through both class-based and a large-scale real-time web-based simulation. We present the results of quantitative analysis of students' oral production. The goal was to show whether simulation-based instruction contributes to significant progress in oral language production in English. The results indicate that students progressed significantly in four language-related areas: vocabulary, pronunciation, variety of expression and grammar.

Sharifi, Ghanizadeh and Jahedizadeh (2017). Conducted a study delved into a language learning model in the domain of English as a foreign language (EFL), i.e., simulation in Iran. The term simulation is used to describe the activity of producing conditions which are similar to real ones. We hypothesized that simulation plays a role in middle school students' perceptions of classroom activities (i.e., interest, challenge, choice, and joy). It was also conjectured that simulation affects foreign language achievement. To do so, the study utilized an experimental design consisting of 51 female participants ( 25 learners in the control group and 26 students in the experimental group). The results demonstrated the positive role of simulation in students' perceptions of classroom activities and their language achievement. A semi- structured interview was also held at the end of the study with a number of students in experimental group to investigate student's attitudes and emotional reactions towards simulation.

Taher and Khan (2015) conducted a study aimed to explore the impact of the use of computer simulation design methods on students' learning for circuit construction in an undergraduate technical course.

This study presents the findings of the research study which tested the hypothesis by investigating three key questions: question one: Does the use of simulation improve students 'learning outcomes? Question two: How do faculty members perceive the use and effectiveness of simulation in the delivery of technical course content? Question three: How do students perceive the instructional design features embedded in the simulation program such as exploration and scaffolding support in learning new concepts?

The paper also discusses the other aspects of findings which reveal that simulation by itself is not very effective in promoting student learning, but simulation becomes effective in promoting

student learning when used in conjunction with hands-on approach i.e. hybrid or combinational instructional strategy. Furthermore, the paper presents recommendations for improving student learning, viz a viz simulation-based and hands-on labs.

Ayudhya (2015). Conducted a study aimed to examine Effectiveness of simulation in developing English communicative speaking skill in learners with different English proficiency. The subjects included 100 Rajabhat Bachelor's degree English major (Semester 2/2013) students. They were divided as 2 groups based on their English proficiency using the scores they got from the university 
fundamental course. 40 students with the first 40 highest scores were assigned as a high English proficiency group and the other 40 students with the first 40 lowest scores were assigned as a low English proficiency group. The other 20 students who had the scores between these two groups were cut off. Research instruments included English Communicative Speaking Online Learning Package Using Simulation and English Communicative Speaking Test. A simple pre- and posttest comparison study was used as the research methodology. The results revealed that the mean of communicative speaking testing scores in the posttest of total 80 subjects was significantly higher than in the pretest at .05 significant level. Comparing between the results obtained from the subjects with high and low English proficiency level presented that in the high group, the mean of communicative speaking testing scores in the posttest was significantly higher than in the pretest $(\mathrm{t}=11.77)$ and in the low group, the mean of communicative testing scores in the posttest was significantly higher than in the pretest $(\mathrm{t}=$ $14.31)$ at .05 significant level. The results were discussed in terms of the importance of simulation in conveying understanding to the learners and the appropriate use of simulation in learners with different English proficiency according to a performance pyramid.

Ezeudu \& Ezinwanne (2013) conducted a study aimed to investigate the effect of simulation on students' achievement in senior secondary school chemistry in Enugu East Local Government Area of Enugu State, Nigeria. The design of the study was quasi-experimental with specifically the pre-test and post-test. The sample of the study consisted of 159 senior secondary school students (80 males and 79 females) randomly selected from two schools out of the secondary schools in Enugu

East Local Government Area of Enugu State, Nigeria. The experimental group comprised of 39 males and 39 females (78 students) while the control had 41 males and 40 females (81student). Two research questions and two hypotheses guided the study. The achievement test in simulation (ATIS) was used to collect data on the student achievement. Means and standard deviation were used to answer the research questions while the t-test was used to test the hypotheses a 0.05 level of significance. The results showed that simulation increased students' achievement in chemistry more than the conventional method. There was no significant different in the achievement of male and female students on the chemistry concepts. Based on the results it was recommended that chemistry teachers should be re-trained on the use of simulation in teaching while the government and stake holders in Education should sponsor the purchase of simulators to be used in teaching chemistry in schools.

Cigrik \& Ergul ( 2009) conducted a study aimed to investigate effect of simulation based teaching on the student achievement and attitude which subject of electrostatic induction in Turkey. For this purpose, control ( 2 class, 57 person) and experiment ( 2 class, 59 
person) groups were determined. During the 5 lesson period, experiment group were held with the simulation. After the study, it was found that simulations have improved students' success on subject of induction and there is a significant difference between experimental and control groups. On the other hand, using simulation did not indicate a significant effect on students' attitudes in this study.

Ekker (2004) conducted empirical research into simulations applied to education in Portugal. The author analyzed data on 241 subjects who had participated in various editions of IDEELS, examining satisfaction levels and attitudes. The participants had different roles as negotiators, technical consultants, activists or journalists within the "Eutropian Federation Simulation". The threeweek simulation consisted of message exchanges, written proposals and "live" conference situations. The software used was a web-based interface driven by a database server. The project resorted to a webbased questionnaire to measure students' satisfaction, personal experiences and attitudes towards the simulation. Findings revealed that students experienced satisfaction during the simulation and they were activated as the simulation invigorated learning. The simulation was a reality in itself and participants responded actively at all times during the simulation period.

Through reviewing the related literature, it is noticed that most of these studies like ( Angelini, 2019) and (Ayudhya, 2015) studied the effects of simulation on speaking skill for English Language Learners.

Also, some of studies like ( Cigrik \& Ergul, 2009) and ( Taher \& Khan, 2014) studied the effect of simulation on students' achievement.

In this study, the researcher used simulation to investigate its' effect on students' speaking and reading skills.

The importance of this study that there are no studies conducted about simulation in speaking and reading skills for the third grade students in Jordan. So, the researcher hopes that this study will be an addition to the previously mentioned studies in this field.

\section{Methodology}

\section{The population of the Study}

The population of the study contains of all the third grade students' at the Private schools in AlKarak Directorate of Education in the semester 2020/2021 and whose number was ( 365 ).

\section{The sample of the Study}

The sample of the study consists of Males and Females of the third grade students who are studying At Al-Tamkeen Academy During the semester 2020/2021, and whose total number was (30) and they were selected Purposefully ( the main reason for choosing this sample because the Academic specialization of the researcher is English classroom teacher and teaching the primary stage "first three grades" and we have to prepare the students in this stage with the main skills to be efficient learners and encouraging them to practice the 

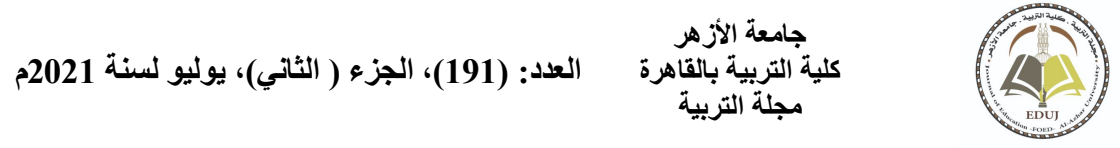

language). The researcher divided the sample into two groups; control and experimental groups.

\section{The methodology of the study}

The method which used in this study in order to achieve its goal and answers the two research questions is the experimental methodology.

\section{Instruments of the study}

The researcher used a Computerized Simulation-Based Educational program in providing the Third grade students with reading and speaking skills in English Language. The researcher set the objectives of the program which are developing students' speaking and reading skills. Also, the researcher set the educational activities that will develop these skills.

And to build this instrument the researcher used the scanner to upload the chosen units on the website, then using the programming languages to add sounds, effects, colors and videos.

-The researcher designed an observation cards for the two skills based on the instructional material of the third grade English book according to Likert scale and consisted of the main sub-skills that the students should acquire in the reading and speaking skills.

And to build this study the researcher reviewed the previous literature and returned to the general frameworks of the curriculum for the primary educational stage in Jordan and she wrote the main subskills of each skill.

- pre/post tests to find out the developing in the two skills after teaching students with a Simulation-Based Educational program.

And to build this study the researcher designed a pre/post test to measure the developing the students' speaking and reading skills. The test was prepared based on the specification table which prepared by the researcher, where the number of questions for each skill was determined based on the relative weight for each skill.

\section{Validity:}

The validity of the instruments was assured by submitted the program to a panel of 5 holders of a $\mathrm{PhD}$ in Information Technology. And submitted the observation cards and the pre/post test to 14 members, 5 members who are holding PhD in methods of Teaching English from the Faculty of Educational Science, 4 English Language supervisors at Al-karak Directorate of Education and 4 English Language teachers at Al-karak Directorate of Education.

The jury members were asked to judge the study instruments and determine if they are suitable for the purpose of the study, They were asked to add, delete or modificate any of the instruments study. 


\section{Discrimination \& Difficulty coefficient}

The test was applied to an pilot sample of (30) male and female students selected randomly from within the study population and outside of her sample, in order to determine the test time and to ensure the clarity of the meanings and test instructions, and also to verify the psychometric properties of the test and its items, and discrimination coefficients were calculated using the corrected correlation coefficient. (corrected Correlation) and the difficulty of the test items, with the proportion of correct answers, as shown in table(1):

Table (1)

The discrimination \& difficulty coefficient of the test items

\begin{tabular}{cccccc}
\hline $\begin{array}{c}\text { Ite } \\
\mathbf{m}\end{array}$ & $\begin{array}{c}\text { Discriminatio } \\
\mathbf{n} \\
\text { Coefficient }\end{array}$ & $\begin{array}{c}\text { Difficulty } \\
\text { coefficien } \\
\mathbf{t}\end{array}$ & $\begin{array}{c}\text { Ite } \\
\mathbf{m}\end{array}$ & $\begin{array}{c}\text { Discriminatio } \\
\mathbf{n} \\
\text { coefficient }\end{array}$ & $\begin{array}{c}\text { Difficulty } \\
\text { coefficien } \\
\mathbf{t}\end{array}$ \\
\hline \multicolumn{4}{c}{ Reading skill } & & \multicolumn{3}{c}{ Speaking Skill } \\
\hline 1 & .31 & .36 & 1 & .31 & .36 \\
2 & .39 & .36 & 2 & .39 & .36 \\
3 & .66 & .41 & 3 & .66 & .41 \\
4 & .61 & .45 & 4 & .61 & .45 \\
5 & .42 & .39 & 5 & .42 & .39 \\
6 & .27 & .58 & 6 & .27 & .58 \\
7 & .54 & .38 & 7 & .54 & .38 \\
8 & .33 & .41 & 8 & .33 & .41 \\
\hline
\end{tabular}

\section{Stability of the test}

The stability of the test was verified by the Cronbach's alpha internal consistency on the pilot sample $(n=30)$ as in table (2):

Table (2)

The Cronbach's alpha internal consistency stability coefficient

\begin{tabular}{ccc}
\hline Skill & Items & stability coefficient \\
\hline Reading & 11 & .91 \\
\hline Listening & 10 & .89
\end{tabular}

\section{Study procedures}

The researcher followed the following procedures:

First: The course material was chosen to be taught using the strategy (Computerized Simulation-Based Educational program.), and in a manner consistent with the distribution of the curriculum, in terms of 
the number of classes, activities and their time, while ensuring the equal application of the method. And those with experience in preparing it, then it was arbitrated by specialists and amended in the light of their suggestions.

The educational material for the unit was prepared according to the following stage:

First: Analysis of the content of the two units, where the objectives of the lessons they included, the basic and subsidiary concepts of each academic topic, and the relationships between them were enumerated.

Second: Designing the study instruments which are ( a questionnaire, observation cards. Pre/post test and a computerized simulation-based educational program).

Third: Divided the selected classes from the selected school into two groups: control (not exposed to the method) and experimental (Computerized Simulation-Based Educational program), as was previously explained in the study sample.

Fourth: The experimental group students were taught using the experimental method (Computerized Simulation-Based Educational program)

Fifth: The parity of the two groups was ascertained by using a test (T) for independent samples on members of the study sample from the control and experimental groups in the pre-measurement. Tables $(3,4$ \& 5) shows that:

Table (3)

Independent $t$ test to achieve the differences between control and experimental groups on reading skill on the pre-test

\begin{tabular}{|c|c|c|c|c|c|c|}
\hline Domain skill & Group & $\mathbf{N}$ & Mean & $\begin{array}{c}\text { Std. } \\
\text { Deviation }\end{array}$ & Df $T$ value & Sig \\
\hline \multirow{2}{*}{$\begin{array}{l}\text { The reader is } \\
\text { address him/her } \\
\text { self while } \\
\text { reading }\end{array}$} & Control & 15 & .2667 & .45774 & \multirow[b]{2}{*}{-.386} & \multirow[b]{2}{*}{.702} \\
\hline & experimental & 15 & .3333 & .48795 & & \\
\hline \multirow{2}{*}{$\begin{array}{l}\text { Read with less } \\
\text { mistakes }\end{array}$} & Control & 15 & .2667 & .45774 & \multirow{2}{*}{-.386} & \multirow{2}{*}{.702} \\
\hline & experimental & 15 & .3333 & .48795 & & \\
\hline \multirow{2}{*}{$\begin{array}{l}\text { Read the new } \\
\text { words } \\
\text { contextually }\end{array}$} & Control & 15 & .3333 & .48795 & \multirow{2}{*}{.386} & \multirow[t]{2}{*}{.702} \\
\hline & experimental & 15 & .2667 & .45774 & & \\
\hline \multirow{2}{*}{$\begin{array}{l}\text { Read with high } \\
\text { self-confidence }\end{array}$} & Control & 15 & .2667 & .45774 & \multirow{2}{*}{-.386} & \multirow{2}{*}{.702} \\
\hline & experimental & 15 & .3333 & .48795 & & \\
\hline Enjoy while & Control & 15 & .2667 & .45774 & .000 & 1.000 \\
\hline
\end{tabular}


Ala'a Yahya Al-Fogara

Prof. Khalaf Al-Sagrat
The Effectiveness of a Computerized SimulationBased Educational Program in Developing Reading and speaking skills for the 3rd Grade

\begin{tabular}{|c|c|c|c|c|c|c|}
\hline Domain skill & Group & $\mathbf{N}$ & Mean & $\begin{array}{c}\text { Std. } \\
\text { Deviation }\end{array}$ & Df $T$ value & Sig \\
\hline reading & experimental & 15 & .2667 & .45774 & & \\
\hline \multirow{2}{*}{$\begin{array}{l}\text { Stop in the } \\
\text { correct position }\end{array}$} & Control & 15 & .2667 & .45774 & \multirow{2}{*}{-.386} & \multirow{2}{*}{.702} \\
\hline & experimental & 15 & .3333 & .48795 & & \\
\hline \multirow{2}{*}{ Read loudly } & Control & 15 & .2667 & .45774 & \multirow{2}{*}{-.386} & \multirow{2}{*}{.702} \\
\hline & experimental & 15 & .3333 & .48795 & & \\
\hline \multirow{2}{*}{$\underset{\text { text }}{\text { Read a simple }}$} & Control & 15 & .3333 & .48795 & \multirow{2}{*}{.386} & \multirow{2}{*}{.702} \\
\hline & experimental & 15 & .2667 & .45774 & & \\
\hline \multirow{2}{*}{$\begin{array}{l}\text { Read words and } \\
\text { sentences } \\
\text { correctly }\end{array}$} & Control & 15 & .3333 & .48795 & \multirow{2}{*}{.386} & \multirow{2}{*}{.702} \\
\hline & experimental & 15 & .2667 & .45774 & & \\
\hline \multirow{2}{*}{$\begin{array}{l}\text { Distinguish } \\
\text { between letters } \\
\text { and chants }\end{array}$} & Control & 15 & .3333 & .48795 & \multirow{2}{*}{.000} & \multirow{2}{*}{1.000} \\
\hline & experimental & 15 & .3333 & .48795 & & \\
\hline \multirow{2}{*}{$\begin{array}{l}\text { Pronoun the } \\
\text { letters correctly }\end{array}$} & Control & 15 & .2667 & .45774 & \multirow{2}{*}{-.386} & \multirow{2}{*}{.702} \\
\hline & experimental & 15 & .3333 & .48795 & & \\
\hline \multirow{2}{*}{$\begin{array}{l}\text { Total of Reading } \\
\text { skill }\end{array}$} & Control & 15 & 3.2000 & 1.74028 & \multirow{2}{*}{-.296} & \multirow{2}{*}{.770} \\
\hline & experimental & 15 & 3.4000 & 1.95667 & & \\
\hline
\end{tabular}

As seen in table (3)There were no statistically significant differences at the level of significance $(\alpha \leq 0.05)$ between the mean scores of the members of the experimental and control groups in the pre-measurement on the achievement test, as the values of $(\mathrm{t})$ calculated for the total reached $=(-0.296)$, which indicates the existence equivalence between the control and experimental groups in the level of reading skill for the 3rd grade Students in the English language.

Table (4)

Independent t test to achieve the differences between control and experimental groups on Speaking skill on the post test

Domain skill Group N Mean $\begin{gathered}\text { Std. } \\ \text { Deviation }\end{gathered}$ Df T value Sig

\begin{tabular}{|c|c|c|c|c|c|}
\hline \multirow{2}{*}{ Be fluent } & Control & $15 \quad .20$ & .25 & \multirow{2}{*}{-.357} & \multirow{2}{*}{.724} \\
\hline & experimental & .23 & .26 & & \\
\hline \multirow{2}{*}{$\begin{array}{l}\text { Attract } \\
\text { students' } \\
\text { attention }\end{array}$} & Control & .13 & .23 & \multirow{2}{*}{-1.122} & \multirow{2}{*}{.271} \\
\hline & experimental & .23 & .26 & & \\
\hline
\end{tabular}




\begin{tabular}{|c|c|c|c|c|c|c|}
\hline ي)، يوليو لسنة 2021م & 191)، الجزء ( الثانه & لعدد: ( ) ) & & كلية التربية بالزة التربة & 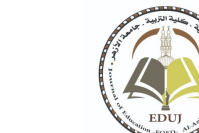 & \\
\hline Domain skill & Group & $\mathbf{N}$ & Mean & $\begin{array}{c}\text { Std. } \\
\text { Deviation }\end{array}$ & Df $T$ value & Sig \\
\hline Use body & Control & 15 & .20 & .25 & & \\
\hline $\begin{array}{l}\text { language while } \\
\text { speaking }\end{array}$ & experimental & 15 & .17 & .24 & .367 & .716 \\
\hline Organize the & Control & 15 & .20 & .25 & 357 & 724 \\
\hline ideas & experimental & 15 & .23 & .26 & ו & .124 \\
\hline Produce & Control & 15 & .13 & .23 & & \\
\hline $\begin{array}{l}\text { grammatical } \\
\text { sentences }\end{array}$ & experimental & 15 & .17 & .24 & -.386 & .702 \\
\hline Pronounce & Control & 15 & .17 & .24 & & \\
\hline $\begin{array}{l}\text { sounds } \\
\text { correctly }\end{array}$ & experimental & 15 & .20 & .25 & -.367 & .716 \\
\hline Sneak loudly & Control & 15 & .13 & .23 & -386 & 702 \\
\hline Speak louniy & experimental & 15 & .17 & .24 & & \\
\hline Speak with & Control & 15 & .17 & .24 & & \\
\hline $\begin{array}{l}\text { high self- } \\
\text { confidence }\end{array}$ & experimental & 15 & .17 & .24 & .000 & 1.000 \\
\hline Total of & Control & 15 & 1.33 & .58 & -1.082 & 288 \\
\hline Speaking skill & experimental & 15 & 1.57 & .59 & & \\
\hline
\end{tabular}

As seen in table (4)There were no statistically significant differences at the level of significance $(\alpha \leq 0.05)$ between the mean scores of the members of the experimental and control groups in the pre-measurement on the achievement test, as the values of $(\mathrm{t})$ calculated for the total reached $=(-1.082)$, which indicates the existence equivalence between the control and experimental groups in the level of Speaking skills for the 3rd grade Students in the English language.

\section{Study variables:}

The study included the following variables:

1. Independent variables:

a. The teaching method has two levels (the computerized simulationbased Educational program, and the regular method).

2. The dependent variable: academic achievement. 


\section{Statistical processors} used:

To answer the study questions, the following statistics were

- One Way ANOVA

- independent $t$ test.

- Discrimination \& Difficulty coefficient

- The Cronbach Alpha equation for calculating internal consistency constancy.

- The Black modified gain equation to know its effectiveness of the computerized simulation-based Educational program In developing reading and speaking skills for the 3rd grade Students in the English language as follows:

The value of the modified gain $=(\mathrm{M} 2-\mathrm{M} 1 / \mathrm{N}-\mathrm{M} 1)+(\mathrm{M} 2-\mathrm{M} 1 /$ N)

Where:

R1 the average of pretest scores.

M2 Average score for post-test.

N Great Mark of the Test.

\section{Discussions}

Q1: What is the effectiveness of a Computerized Simulation-Based Educational program on developing students' reading and speaking skills between the experimental group (which was taught using a computerized simulation-based educational program) and the control group (which was taught by the usual way)?

To answer this question:

To achieve the differences in reading Skill between control and experimental groups on the pre test an independent $t$ test has been used as in table (5): 


\section{Table (5)}

independent t test to achieve the differences between control and experimental groups on reading Skill on the post test

\begin{tabular}{|c|c|c|c|c|c|c|}
\hline Domain skill & Group & $\mathbf{N}$ & Mean & $\begin{array}{c}\text { Std. } \\
\text { Deviation }\end{array}$ & Df $T$ value & Sig \\
\hline $\begin{array}{c}\text { The reader is } \\
\text { address }\end{array}$ & & 15 & .4000 & .50709 & \multirow{2}{*}{\multicolumn{2}{|c|}{$\begin{array}{ll}-2.928 .007\end{array}$}} \\
\hline $\begin{array}{c}\text { him/her self } \\
\text { while reading }\end{array}$ & experimental & 15 & .8667 & .35187 & & \\
\hline \multirow{2}{*}{$\begin{array}{l}\text { Read with less } \\
\text { mistakes }\end{array}$} & Control & 15 & .4000 & .50709 & \multirow[b]{2}{*}{-2.928} & \multirow[b]{2}{*}{.007} \\
\hline & experimental & 15 & .8667 & .35187 & & \\
\hline \multirow{2}{*}{$\begin{array}{l}\text { Read the new } \\
\text { words } \\
\text { contextually }\end{array}$} & Control & 15 & .4000 & .50709 & \multirow[b]{2}{*}{-3.630} & \multirow[b]{2}{*}{.001} \\
\hline & experimental & 15 & .9333 & .25820 & & \\
\hline \multirow{2}{*}{$\begin{array}{l}\text { Read with high } \\
\text { self-confidenc } \epsilon\end{array}$} & Control & 15 & .4000 & .50709 & \multirow{2}{*}{-3.630} & \multirow[b]{2}{*}{.001} \\
\hline & Experimental & $1 \mathrm{c} 5$ & .9333 & .25820 & & \\
\hline \multirow{2}{*}{$\begin{array}{l}\text { Enjoy while } \\
\text { reading }\end{array}$} & Control & 15 & .4000 & .50709 & \multirow{2}{*}{-2.928} & \multirow{2}{*}{.007} \\
\hline & experimental & 15 & .8667 & .35187 & & \\
\hline \multirow{2}{*}{$\begin{array}{l}\text { Stop in the } \\
\text { correct } \\
\text { position }\end{array}$} & Control & 15 & .4000 & .50709 & \multirow[b]{2}{*}{28} & \multirow{2}{*}{.000} \\
\hline & experimental & 15 & 1.0000 & .00000 & & \\
\hline Read loudly & $\begin{array}{c}\text { Control } \\
\text { experimental }\end{array}$ & $\begin{array}{l}15 \\
15\end{array}$ & $\begin{array}{l}.6000 \\
.9333\end{array}$ & $\begin{array}{l}.50709 \\
.25820\end{array}$ & -2.269 & .031 \\
\hline \multirow{2}{*}{$\underset{\text { text }}{\text { Read a simple }}$} & Control & 15 & .4667 & .51640 & \multirow{2}{*}{\multicolumn{2}{|c|}{$\begin{array}{ll}-2.479 .019\end{array}$}} \\
\hline & experimental & 15 & .8667 & .35187 & & \\
\hline \multirow{2}{*}{$\begin{array}{l}\text { Read words } \\
\text { and sentences } \\
\text { correctly }\end{array}$} & Control & 15 & .5333 & .51640 & \multirow{2}{*}{\multicolumn{2}{|c|}{$\begin{array}{ll}-2.683 & .012\end{array}$}} \\
\hline & experimental & 15 & .9333 & .25820 & & \\
\hline \multirow{2}{*}{$\begin{array}{l}\text { Distinguish } \\
\text { between letters } \\
\text { and chants }\end{array}$} & Control & 15 & .3333 & .48795 & \multirow{2}{*}{\multicolumn{2}{|c|}{$\begin{array}{ll}-2.824 .009\end{array}$}} \\
\hline & experimental & 15 & .8000 & .41404 & & \\
\hline \multirow{2}{*}{$\begin{array}{l}\text { Pronoun the } \\
\text { letters } \\
\text { correctly }\end{array}$} & Control & 15 & .3333 & .48795 & \multirow{2}{*}{\multicolumn{2}{|c|}{$\begin{array}{lll}-2.824 & .009\end{array}$}} \\
\hline & experimental & 15 & .8000 & .41404 & & \\
\hline $\begin{array}{c}\text { Total of } \\
\text { Reading skill } \\
\end{array}$ & $\begin{array}{c}\text { Control } \\
\text { experimental }\end{array}$ & $\begin{array}{l}15 \\
15 \\
\end{array}$ & $\begin{array}{l}4.6667 \\
9.8000 \\
\end{array}$ & $\begin{array}{c}1.75933 \\
.77460 \\
\end{array}$ & \multicolumn{2}{|c|}{$-10.342 .000$} \\
\hline
\end{tabular}


As seen in table (5) there is a statistical significant differences at $(\alpha<0.05)$ between control group and experimental group were T value Total reading skill $=(-10.342)$, due to experimental group also on all its domain skills; i.e that an effect of a computerized simulation-based Educational program In developing reading skill for the 3rd grade Students in the English language.

To achieve the differences in Speaking skill between control and experimental groups on the pre test an independent $t$ test has been used as in table (6):

\section{Table (6)}

independent $t$ test to achieve the differences between control and experimental groups on Speaking skill on the post test

\begin{tabular}{|c|c|c|c|c|}
\hline Domain skill & Group & N Mean & $\begin{array}{c}\text { Std. } \\
\text { Deviation }\end{array}$ & Df T value Sig \\
\hline \multirow{2}{*}{ Be fluent } & Control & .27 & .26 & \multirow{2}{*}{$-3.500 .002$} \\
\hline & Experimental & .50 & .00 & \\
\hline \multirow{2}{*}{$\begin{array}{l}\text { Attract students' } \\
\text { attention }\end{array}$} & Control & .13 & .23 & \multirow{2}{*}{$-4.025 .000$} \\
\hline & Experimental & .43 & .17 & \\
\hline Use body & Control & .23 & .26 & \multirow[b]{2}{*}{-4.000 .000 } \\
\hline $\begin{array}{l}\text { language while } \\
\text { speaking }\end{array}$ & Experimental & .50 & .00 & \\
\hline \multirow{2}{*}{$\begin{array}{l}\text { Organize the } \\
\text { ideas }\end{array}$} & Control & .20 & .25 & \multirow{2}{*}{$-2.928 .007$} \\
\hline & Experimental & .43 & .17 & \\
\hline \multirow{2}{*}{$\begin{array}{c}\text { Produce } \\
\text { grammatical } \\
\text { sentences }\end{array}$} & Control & .20 & .25 & \multirow[t]{2}{*}{28} \\
\hline & Experimental & .47 & .13 & \\
\hline \multirow{2}{*}{$\begin{array}{c}\text { Pronounce } \\
\text { sounds correctly }\end{array}$} & Control & .13 & .23 & \multirow{2}{*}{$-4.025 .000$} \\
\hline & Experimental & .43 & .17 & \\
\hline \multirow{2}{*}{ Speak loudly } & Control & .20 & .25 & \multirow{2}{*}{-3.630 .001 } \\
\hline & Experimental & .47 & .13 & \\
\hline \multirow{2}{*}{\multicolumn{2}{|c|}{$\begin{array}{l}\text { Speak with high Control } \\
\text { self-confidence Experimental }\end{array}$}} & .17 & .24 & \multirow{2}{*}{$-4.209 .000$} \\
\hline & & .47 & .13 & \\
\hline Total of & Control & 1.53 & .55 & \multirow{2}{*}{$-13.229 .000$} \\
\hline Speaking skill & Experimental & $15 \quad 3.70$ & .32 & \\
\hline \multicolumn{5}{|c|}{$\begin{array}{l}\text { As seen in table (6)there is a statistical significant differences } \\
\text { at }(\alpha<0.05) \text { between control group and experimental group were T } \\
\text { value Total Speaking skill = (-13.229), due to experimental group also } \\
\text { on all its domain skills; i.e that an effect of a computerized } \\
\text { simulation-based Educational program In developing Speaking skills } \\
\text { for the 3rd grade Students in the English language. }\end{array}$} \\
\hline \multicolumn{5}{|c|}{$\begin{array}{l}\text { In order to reveal the effectiveness of Computerized } \\
\text { Simulation-Based Educational program, the modified gain equation for } \\
\text { Black was used as in Table (7): }\end{array}$} \\
\hline
\end{tabular}


Table (7)

the modified gain equation for Black to achieve the effectiveness of Computerized Simulation-Based Educational program

\begin{tabular}{lcccccc}
\hline Domain & $\begin{array}{c}\text { Mean of Mean of } \\
\text { pre test post test }\end{array}$ & $\begin{array}{c}\text { The Great } \\
\text { End of } \\
\text { mark }\end{array}$ & & Rawgain & $\begin{array}{c}\text { The } \\
\text { expected }\end{array}$ & $\begin{array}{c}\text { Modified } \\
\text { gain }\end{array}$ \\
\hline Reading & 3.40 & 9.80 & 11 & .84 & .58 & 1.42 \\
Speaking & 1.57 & 3.70 & 4 & .88 & .53 & 1.41 \\
Total & 4.97 & 13.50 & 15.00 & 1.72 & 1.11 & 2.83 \\
\hline
\end{tabular}

It is noticed from the table (7) that the modified gain values exceeded the cut-off score according to Black, which indicates the effectiveness of Computerized Simulation-Based Educational program.

O2: Are there anv statistical significant differences at $(\alpha<0.05)$ between the students' performance in reading and speaking skills due to the Computerized Simulation-Based Educational program?

To answer this question One Way ANOVA has been used as in table (6):

Table (8)

One Way ANOVA to achieve the differences between the students' performance in the reading skill due to the Computerized Simulation-Based Educational program

\begin{tabular}{lllllll}
\hline Skill & N & Mean & $\begin{array}{l}\text { Std. } \\
\text { Deviation }\end{array}$ & $\begin{array}{l}\text { Sum of } \\
\text { Squares }\end{array}$ & Df & $\begin{array}{l}\text { Mean } \\
\text { Square }\end{array}$ \\
\hline Reading & 15 & .45 & .03 & .090 & 42 & .002 \\
\hline Speaking & 15 & .46 & .04 & .094 & 44 & \\
\hline
\end{tabular}

As seen in the table (8) there were no statistical significant differences at $(\alpha<0.05)$ between the students' performance in reading and speaking skills due to the Computerized Simulation-Based Educational program.

\section{Results}

Results of question one: What is the effectiveness of a Computerized Simulation-Based Educational program on developing students' reading and speaking skills between the experimental group (which was taught using a computerized simulation-based educational program) and the control group (which was taught by the usual way)?

The Result indicated there were an Effectiveness of a Computerized Simulation-Based Educational Program In Developing 
Reading and speaking skills for the 3rd Grade Students in The English Language, this result may attributed to: The focus of simulation activities on senses, practice and training, and giving the students the opportunity to practice the individual and group learning, where the student to learns according to his capabilities and needs, Also, simulation provides students with attractive educational environment through which reality is experienced.

Another reason may also be due to the employing of modern techniques and multiple learning modes, varied and fun, which stimulate students to communicate and interact with each other and increased their motivation towards learning, and encouraged them to interact and participate during applying the simulation activities, which contributed to the development of English reading and speaking skills. It may also be due to the simplessity of the software design of the educational material and the characteristics of the students, and the clarity of the steps to the procedures included in it, which contributed to learning reading skill in a better way than the usual methods, the explanation of this result may be due to reasons, including: The activities included in this program help students to develop their reading and speaking skills and using teaching strategies based on groups and individual learning. Also, giving students the opportunity to apply activities and practice the skills on their laptop, tablet and smart phones.

And this result agrees with Angelini (2019) which declared that the results indicated that students progressed significantly in speaking skill. Also, it agrees with Ayudhya (2015) which the results declared that there was an increasing in the student's achievement in the communicative skills.

Results of auestion two: O2: Are there anv statistical significant differences at $(\alpha<0.05)$ between the students' nerformance in reading and speaking skills due to the Computerized Simulation-Based Educational program?

The result indicated that no statistical significant differences at $(\alpha<0.05)$ between the students' performance in reading and speaking skills due to the Computerized Simulation-Based Educational program This can be attributed to the fact that reading and speaking skills have been improved at the same level, because this method allows the student to rely on himself in collecting and gaining information, which increase his self-confidence, and gives him the opportunity to correct his mistakes and his colleagues mistakes. The program activities provide students with the suspense and excitement during practicing the English Language skills, They supply the student with information in an environment in which there is sound, image, sounds effects and videos, and allow him to discover and compete, also provide him with the opportunity to cooperate with the other students. 


\section{The Recommendations}

Based on the results of this study, the researcher recommended the Interesting in teaching reading skill to students in the basic stage using computer simulation programs; Because of its impact on students' attention and their motivation to learn English.

1- The importance of training the teachers to design a Computerized simulation-based Educational program for all the English skills..

2- The Ministry of Education in Jordan should increase attention and focus on employing technology and computerized educational programs based on simulations in teaching different skills And the use of this technology in the classroom of schools.

3- Conducting further research and studies on computer simulation programs in educational stages Various, and other topics and in other provinces of the homeland.

4- Conducting more research and studies in which the educational material is prepared using the simulation method, and presenting it to students for reference in addition to the textbook, after the Students have been trained on the mechanism of using the virtual environment. 


\section{References}

Adam Blatner, M.D. (2002). Role Playing In Education. https://www.academia.edu/

Adler, C. R. (Ed.). (2001). Put reading first: The research building blocks for teaching children to read. Jessup, MD: ED Pubs.

AlNatour, A \& Hijazi, D. (2018). The impact of using Electronic games on teaching English vocabulary for kindergarten students.US-China Foreign Language, Vol (16), No(4), 193205.

Ajarmeh, N. (24/9/2018). The low results in the English Language Assessment. ALGhad Newspaper. Retrieved on https://alghad.com

Angelini, M, L. (2019). Developing English speaking skill through simulation-based-instruction. Teaching English with Technology. 19(2), 3-20.

Ayudhya, P, S. (2015). Effectiveness of simulation in developing English communicative speaking skill in learners with different English proficiency. Journal of Simulation /Gaming for learning and development (SGID). Vol(1), N(1). 22-33.

Baker, L. L., \& Gaut, D.A. (2002). Communication (8th ed.). Boston: Allyn and Bacon.

Bojovic, M. (2010). Reading skills and Reading Comprehension in English for Specific Purposes. Conference paper. 23 and 24 September 2010. Slovenia.

Cambridge Business English Dictionary (2011): Cambridge University Press.

Cigrik, E \& Ergul, R. (2009). The investigation of the effect of simulation based teaching on the student achievement and attitude in electrostatic induction. Procedia - Social and Behavioral Sciences Volume 1, Issue 1, Pages 2470-2474

Coffman, T. (2006).Using simulation to enhance teaching and learning ; Encouraging the creative process. VSTE Journal. Vol (21), No (2).

De Jong, T, \& Lane, J \& Sharp, S. (2012). The Efficiency of Simulation as a pedagogy in Facilitating pre-service teachers' learning about emotional self-regulation and its' relevance to the teaching profession. Australian Journal of teacher Education. Vol (73), No (3).

Ekker, K. (2004). User satisfaction and attitudes towards an internetbased simulation. In D. Kinshuk, G. Sampson, \& P

Ezeudu, F. O. \& Ezinwanne, O. P. (2013). Effect of simulation on students' achievement in Senior Secondary School Chemistry in 
Enugu East Local Government Area of Enugu State, Nigeria. Journal of Education and Practice, 4 (19), 84-89

Grellet, F. (1983). Developing Reading Skill. London: Cambridge University press.

Harmer, J. (2003). The Practice of English Language Teaching, 3rd Edition. London: Longman.

Harmer, J. (2007). How teach English . Pearson Educational Limited. P (288).

Harmer, J. (2007). How to teach English. Longman: NewYork.

Harvey, S., \& Goudvis, A. (2000).Strategies that work teaching comprehension to enhance understanding. York, ME: Stenhouse Publishers.

Ismail, H \& Syahruza , J \& Basuk (2017). Improving the students' reading skill through translation method. Journal of English Education. (JEE). Vol (2), No(2).

Kaufman, D. (2016). Enhancing Teacher Education with Simulations

Kodotchigova, M . (2002). Role Play in Teaching Culture: Six Quick Steps for Classroom Implementation. The Internet TESL Journal, Vol. V(3), No. 7,

Krebt, D. (2017). The Effectiveness of Role Play Techniques in Teaching Speaking for EFL College Students, Journal of Language Teaching and Research. Vol. 8, No. 5, pp. 863-870

Kucuoglu, H. (2013). Improving reading skills through effective reading strategies. Procedia-Social and Behavioral Sciences. Vol (70), p(709-714).

Learning skills and tutoring centre (2016). Improving Reading skills. Sacramento city college.

Nunan, D. (1999). Second Language Teaching and Learning. Masschyserts: Heinle and Heinlepulicher

Nunan, D. (2003). Practical English Language Teaching. North America: McGraw Hill / Contemporary.

Oczkus, L. D. (2003). Reciprocal teaching at work strategies for improving reading comprehension. Newark, DE: International Reading Association.

Rohani, M \& Pougharib, B. (2013). The effects of games on learning Vocabulary. International Research Journal of Applied and Basics Science. 4(11). 3540-3545.

Serafini, F. (2004). Lessons in comprehension explicit instruction in the reading workshop. Portsmouth, NH: Heinemann. 
Sharifi, A \& Ghanizadeh, A \& Jahedizadeh. S. (2016). The effect of simulation on Middle school students' perceptions of classroom activities and their foreign language achievement : A mixedMethd Approach. International Electronic Journal of Elementary Education. 9(3). 667-680.

Shaw, Carolyn M. (2010).Designing and using simulations and roleplay exercises. The International Studies Encyclopedia. (Ed) Robert A. Denemark. 15. Nov. 2015. DOI 10.1111/b.9781444336597.2010.Srinivas Rao, P. (2019). The importance of speaking skills English Classroom. Alford Council of International English and Literature Journal (ACIELJ).Vol(2).

Ur, Peny. 1996. A Course in Language Teaching. Cambridge university press. 